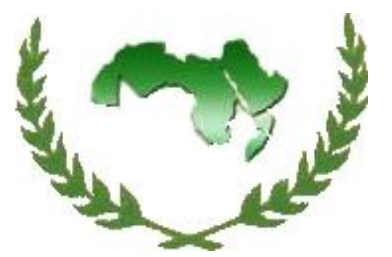

Arab Univ.

J. Agric. Sci.,

Ain Shams Univ.,

Cairo, 15(1), 169-176, 2007

\title{
EFFECT OF ETHYL SALICYLIC ACID VAPOUR ON SPROUTING AND ROTS INCIDENCE OF POTATO TUBERS UNDER LONG-TERM STORAGE(a)
}

\author{
Mostafa $^{1}$, M.H. and E.A.M. Gado ${ }^{1}$ \\ 1- Laboratory of Molecular Plant Pathology, Department of Plant Pathology, Faculty of Agriculture, Ain \\ Shams University, Shoubra El-Kheima, Cairo, Egypt
}

Keywords: Potato tubers, Ethyl salicylic acid vapour, Rots incidence, Inhibition of sprouting, Inducing resistance

\begin{abstract}
The effect of exposing of potato tubers cv. Diamond to ethyl salicylic acid (ES) vapour for different doses and different periods of exposing on rots incidence and sprouting of tubers under long term storage was studied. Expose of tubers to high doses of vapour (resulted from evaporation of 0.5 or $1 \mathrm{ml} /$ liter space) for $6 \mathrm{~h}$ led to appear a very strong harmful effect on exposed tubers stored for 4 months. All tubers were decayed, collapsed and severely infected by rot pathogens. Expose of tubers to middle dose $(0.25 \mathrm{ml} /$ liter space $)$ for 6,12 , 24 , or $48 \mathrm{~h}$ then stored for 4 months at ambient temperature showed variable effects. Six or $12 \mathrm{~h}$ exposing led to slight reduction of rot incidence but it had not effect on sprouting in comparison to non-exposed tubers. On the other hand, exposing, for 24 or $48 \mathrm{~h}$ suppressed sprouting completely and reduced to very great extent rots incidence (\%). Storage of tubers exposed to $0.25 \mathrm{ml} /$ liter for $24 \mathrm{~h}$ at high relative humidity $(\sim 90 \%)$ or under cooling $(6-8 \mathrm{C} \bullet$ ) did not cause any reduction in compound efficiency. Expose of tubers to low dose of ES vapour $(0.125 \mathrm{ml} /$ liter space $)$ for different periods showed that exposing for 6 or $12 \mathrm{~h}$ led to stimulatory effect on sprouting without effect on rots incidence. Twenty four hours exposing led to decrease rots incidence and sprouting.

These results clearly indicated that ES vapour had variable effects on exposed tubers depend upon dose and period of exposing.
\end{abstract}

\section{INTRODUCTION}

Potato tubers stored for long periods for human consumption at ambient temperature or in refrigerators suffer from many deterioration factors. Among these factors, rots and sprouting, which consider the most important factors affecting tubers stored for human consumption.

In order to decrease the deterioration effects of such factors in long-term storage of potato tubers, many attempts were carried out.

One of these attempts is exposing tubers prepared for storage to $\gamma$-irradiation. Although such treatment had been giving positive results for prevention of sprouting, it led to a great increase in tuber losses due to increase of bacterial and fungal rots (Sonnewald, 2001 and Slininger et al 2003).

The first chemical compound used to prevent sprouting was maleic hydrazide, this compound had proved its efficiency in suppression of sprouting, but its using in this respect was stopped owing to its harmful effect on human (Singa and Sihombing, 1983).

Different chemical compounds were tested as sprout inhibitors and for decrease decaying due to rots incidence. Among these compounds, Tecnazene (1, 2, 4, 5 tetra-chloro-3-nitrobenzen) was found to be effective as sprouting inhibitor, but it increase rots incidence (Van et al 1966; Beveridge et al 1981 and Dalziel and Duncan, 1980).

Nowadays, the wide spread sprout suppressant chemical compound is CIPC (isopropyl-N(3 chlorophenyl)- carbamate- antispindle formation factor uses for inhibition of sprouting in potato tubers. This compound and other chemical compounds using for suppression of sprouting had proved its

a. This work was financially supported by Academy of Scientific Research and Technology, Egypt

(Received October 17, 2006)

(Accepted November 27, 2006) 
harmful effect on tuber rot incidence. All available anti-sprouting agents cause a great increase of bacterial and fungal rots (Mondy and Pannamplam, 1985; Pannamplam and Mondy, 1986; Pannamplam and Mondy, 1988and Orr et al 1994).

Salicylic acid (SA) and its derivatives have divers effects on treated plants. At very low concentrations, it acts as inducing resistant agent (Vernooij et al 1994; Nawrath \& Metraux, 1999; Gruner et al 2003 and Rocher et al 2005) but at higher concentration they act as protein synthesis inhibitor (Kwon et al 1997) and alter electron transport and oxidative phosphorylation in mitochondria (Zhixin and Chen, 1999 and Norman et al 2004).

This investigation was aimed to study the effect of one of SA derivative (ethyl salicylic acid, ES) in its vapour condition on incidence of tuber rots and sprouting in long term storage either at ambient temperature or under cooling.

\section{MATERIALS AND METHODS}

All experiments conducted in this study were carried out in Plant Pathology Department, Faculty of Agriculture, Ain Shams University during 2004/2006.

\section{Potato tubers}

Potato tubers (Solanum tuberosum L.) cv. Diamond (middle size $\sim 7 \mathrm{~cm}$ long) was used in all experiments conducted in this study. Newly harvested tubers were collected directly from fields of Kalyobia Governorate. Tubers were washed under running tap water to remove adhered clay soil, left for dryness then exposed to ethyl salicylic acid vapour.

\section{Expose of tubers to ethyl salicylic acid vapour}

Since ethyl salicylic acid solution (ES) is able to evaporate at room temperature, it was used in this study to expose potato tubers to its vapour (Orr et al 1994).

The compound was obtained from Aldrich Chemical Company, inc. (USA).

Cans specified for medical instruments sterilization (17.3 liter volume) were used. Tubers were put in the can and Whatman No.1 filter paper (9 $\mathrm{cm}$ in diameter) was adhered tightly in the middle part of the inner surface of the can cover. Filter paper was supplemented with adjusted volume of ethyl salicylic acid solution. Filter paper was supplemented either with $1,0.5,0.25$ or $0.125 \mathrm{ml} / \mathrm{liter}$ space.

Cans were tightly closed then left at root temperature for either to $6,12,24$ or $48 \mathrm{~h}$. After appropriate period, cans were opened, tubers were taken then irritated in front of ventilator until ethyl salicylic acid smile was completely disappeared.

\section{Storage of potato tubers}

For every particular treatment, 50 tubers were used. After ventilation, tubers were divided into two groups each one contained 25 tubers. Tubers were stored in cartoon boxes either at ambient temperature or in refrigerator $\left(6-8^{\circ} \mathrm{C}\right)$ for 4 months. Three distinct experiments were carried out specially in case of exposing tubers to vapour produced from $0.25 \mathrm{ml} /$ liter space. Tubers were left for natural infection. Healthy, not exposed tubers to ethyl salicylic acid vapour, was stored under the same condition and use as control.

\section{Determination of tuber rot incidence}

Fungal or bacterial tuber rots were determined visually on stored tubers according to rot symptoms. Disease incidence was confirmed by isolation and identification of pathogens association with rots. Fusarium dry rot was identified according to Booth (1971) and a soft rot bacterium was identified according to Bergey's Mannual (1994). Tuber considered rotted if any part of tuber showed rot symptoms. Tubers showed both types of rots were counted twisely.

\section{Determination of sprouting}

After storage either at ambient temperature or under cooling, number of sprouts/ tuber was counted and the length of the longest sprout/ tuber and weigh of sprouts were measured. Tuber considered sprouted even one sprout/ tuber was found. Standard deviation $(\sigma)$ was calculated.

\section{Effect of high relative humidity on sprouting and rots incidence}

To study the effect of high relative humidity on rots incidence and sprouting, 15 healthy tubers were taken from tubers stored for 4 months previously exposed to ES vapour for 24 or not exposed then stored in plastic boxes contained wetted filter papers for 15 days then observed. High relative 
humidity ( $90 \%)$ was maintained by wetting filter papers when needed.

\section{RESULTS}

\section{Effect of exposing of potato tubers to high doses of ES vapour}

Expose of potato tubers (50 tubers) cv. Diamond to vapour pressure resulted from evaporation of 1 or $0.5 \mathrm{ml} /$ liter space for $6 \mathrm{~h}$ led to a very strong harmful effect on exposed tubers stored for 4 months under ambient temperature.

Vapour of ES resulted from evaporation of 1 ml ES/ liter space caused complete collapse of exposed tubers. Different types of rots were shown on all exposed tubers. Dry rot causing by Fusarium spp. and soft rot causing by Erwinia carotovora was appeared on all exposed tubers. Moreover, it was observed the presence of Penicillium rot on exposed tubers. Control non-exposed tubers showed Fusarium tuber rot reached to $16 \%$ and $38 \%$ bacterial sof rot. (Table 1).

Table 1. Effect of exposing of potato tubers cv. Diamond to ES vapour resulted from evaporation of $1 \mathrm{ml} /$ liter space (count from 50 tubers)

\begin{tabular}{|c|c|c|c|}
\hline \multirow[b]{2}{*}{ Treatment } & \multicolumn{3}{|c|}{ Rot* } \\
\hline & $\begin{array}{l}\text { Erwinia } \\
\text { soft rot }\end{array}$ & $\begin{array}{l}\text { Fusarium } \\
\text { tuber rot }\end{array}$ & $\begin{array}{c}\text { Penicillium } \\
\text { rot }\end{array}$ \\
\hline $\begin{array}{l}\text { Control non- } \\
\text { exposed }\end{array}$ & 19 & 8 & 0 \\
\hline Exposed tubers & 50 & 50 & $50 * *$ \\
\hline
\end{tabular}

* Tuber showed two types of rots were counted twisely. ** All types of rots were shown on the same tuber.

Expose of tubers to ES vapour resulted from $0.5 \mathrm{ml} /$ liter space led to appearance a phytotoxic effect on all exposed tubers. In addition to severe fungal and bacterial rots, dry dark lesions were appeared on tuber skin.

\section{Effect of exposing of potato tubers to middle dose of ES vapour}

Potato tubers exposed to ES vapour produced from evaporation of $0.250 \mathrm{ml} /$ liter space for different periods i.e. $6,12,24$ or $48 \mathrm{~h}$ and stored for 4 months at ambient temperature showed that the sprouting of tubers exposed for 6 or $12 \mathrm{~h}$ do not differ from non-exposed tubers. Statistical difference between those periods of exposing and nonexposing tubers in rots incidence was observed (Table 2).

Table 2. Effect of exposing of potato tubers cv. Diamond to vapour of ES produced from $0.250 \mathrm{ml} /$ liter space. Data are average of three distinct experiments, every one contained 50 tubers for each particular treatment and stored for 4 months at ambient temperature

\begin{tabular}{|cccc|}
\hline \multirow{2}{*}{ Treatment } & \multicolumn{3}{c|}{ Rot* $^{*}$} \\
\cline { 2 - 4 } & $\begin{array}{c}\text { Erwinia } \\
\text { soft rot }\end{array}$ & $\begin{array}{c}\text { Fusarium } \\
\text { tuber rot** }\end{array}$ & $\begin{array}{c}\text { Penicillium } \\
\text { rot }\end{array}$ \\
\hline Control & $18.3 \pm 0.97$ & $10.6 \pm 1.81$ & 0 \\
$6 \mathrm{~h}$ & $7.0 \pm 1.0$ & $9.0 \pm 1.0$ & 0 \\
$12 \mathrm{~h}$ & $8.0 \pm 1.0$ & $7.6 \pm 2.29$ & 0 \\
$24 \mathrm{~h}$ & $2.6 \pm 1.3$ & $1.3 \pm 1.67$ & 0 \\
$48 \mathrm{~h}$ & $3.6 \pm 1.9$ & $2.6 \pm 1.7$ & 0 \\
\hline
\end{tabular}

Control means non-exposed tubers.

* Tuber showed two types of rots were counted twisely.

** Mean number of rotted tuber.

On the other hand, exposing for $24 \mathrm{~h}$ or $48 \mathrm{~h}$ led to a significant decrease of rots incidence (Table 2). Bacterial soft rot was decreased from $18.3 \pm 0.97$ in control tubers to $2.6 \pm 1.3$ in tubers exposed for $24 \mathrm{~h}$ and Fusarium tuber rot was decreased from $10.6 \pm 1.81$ to $1.3 \pm 1.67$. The same trend of results was also shown in tubers exposed for $48 \mathrm{~h}$.

Concerning sprouting, data represented in Table (3) illustrated by Fig. (1) indicate that exposing of tubers for 6 or 12 have no effect on sprouting of tubers, either on length of the longest sprout or on the total weights of sprouts/ tuber. Whereas the exposing for 24 or 48 hours showed no sprouting.

To study the effect of high relative humidity on rots incidence and sprouting, 15 healthy tubers were taken from tubers stored for 4 months previously exposed to ES vapour for 24 or not exposed then stored in plastic boxes contained wetted filter papers for 15 days. No any rots were observed on stored tubers. Moreover, no any exposed nonsprouted tubers appeared any initiation of sprouting (Fig. 2). 


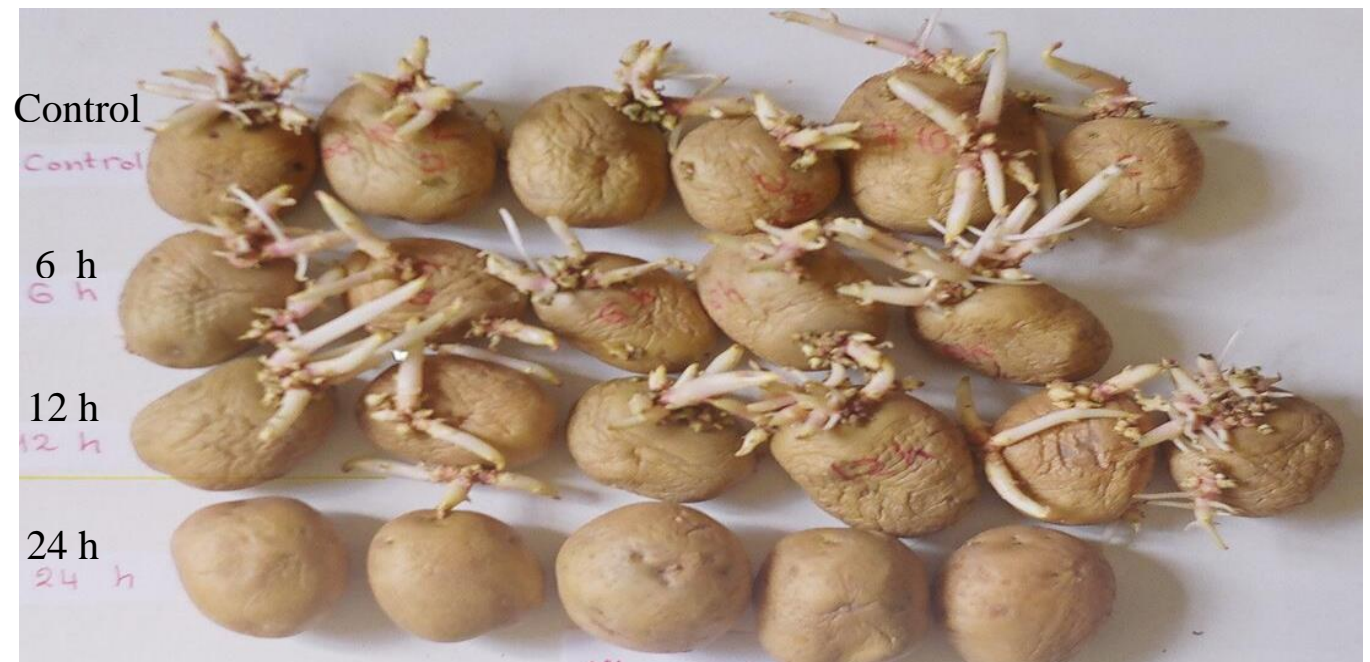

Fig. 1. Examples of tubers exposed to ES vapour produced from $0.250 \mathrm{ml} / \mathrm{liter}$ space for different periods and stored at ambient temperature for 4 months.

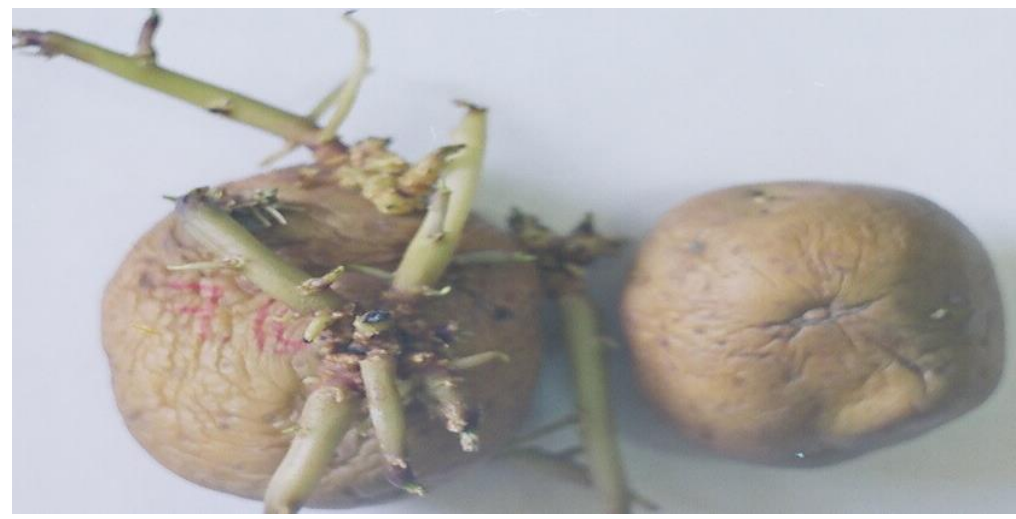

Fig. 2. Example of tubers exposed to ES vapour and stored for 4 months then stored for 15 days at very high relative humidity

Table 3. Effect of exposing of potato tubers to vapour of ES produced from $0.250 \mathrm{ml} /$ liter space on sprouting of tubers stored for 4 months under ambient temperature

\begin{tabular}{|ccc|}
\hline Treatment & $\begin{array}{c}\text { *Average length of } \\
\text { the longest sprout/ } \\
\text { tuber }(\mathrm{cm})\end{array}$ & $\begin{array}{c}\text { *Average weight } \\
\text { of sprouts/ tuber } \\
(\mathrm{g})\end{array}$ \\
\hline Control** & $5.04 \pm 1.85$ & $12.94 \pm 2.92$ \\
$6 \mathrm{~h}$ & $4.96 \pm 1.89$ & $12.19 \pm 5.85$ \\
$12 \mathrm{~h}$ & $5.74 \pm 1.68$ & $11.56 \pm 1.26$ \\
$24 \mathrm{~h}$ & 0 & 0 \\
$48 \mathrm{~h}$ & 0 & 0 \\
\hline
\end{tabular}

* Average of three distinct experiments.

** Control means non treated (exposed) tubers.
To study the effect of storage at cool temperature $\left(6-8^{\circ} \mathrm{c}\right)$ on the efficiency of ES vapour as sprouting inhibitor and inducing resistance agent, tubers were exposed to $\mathrm{ES}$ vapour $(0.250 \mathrm{ml} / \mathrm{liter}$ space) for 24 , then stored at $6-8^{\circ} \mathrm{C}$ for 16 weeks.

The treated stored tubers showed very little count of rotted tubers compared with non-treated tubers (Table 4).

Table 4. Effect of exposure of potato tubers to ES vapour $(0.250 \mathrm{ml} / \mathrm{liter}$ space $)$ stored at 6-8 ${ }^{\circ} \mathrm{c}$ for 4 months

\begin{tabular}{|cccc|}
\hline \multirow{2}{*}{ Treatment } & \multicolumn{3}{c|}{ Rot* $^{*}$} \\
\cline { 2 - 4 } & $\begin{array}{c}\text { Erwinia } \\
\text { soft rot }\end{array}$ & $\begin{array}{c}\text { Fusarium } \\
\text { tuber rot }\end{array}$ & $\begin{array}{c}\text { Penicillium } \\
\text { rot }\end{array}$ \\
\hline Control & 4 & 6 & 0 \\
$24 \mathrm{~h}$ & 1 & 2 & 0 \\
\hline
\end{tabular}

Data of 50 tubers for each particular treatment.

*Tuber showed two types of rots were counted twisely. 
Concerning sprouting, all non-exposed tubers gave short thick sprouts, meanwhile, exposed tuber to ES vapour then stored for 4 months do not sprouted completely (Fig. 3).

To make sure that the treatment has no effect on the inner tissue of exposed tubers, some tubers were taken after $24 \mathrm{~h}$ from the treatment then cut longitudinally and left at root temperature. No any necrosis or discoloration was observed in the inner tissues of potato tubers exposed for 24 or $48 \mathrm{~h}$ (Fig. 4).

\section{Effect of exposing potato tubers to low dose of ES vapour}

Potato tubers were exposed to vapour of ES produced from $0.125 \mathrm{ml} /$ liter space for 6,12 or 24 $\mathrm{h}$, then stored for 4 months under ambient temperature $\left(18-23^{\circ} \mathrm{C}\right)$.

No any difference in bacterial or Fusarium rot incidence was shown between treated and untreated tubers at all periods of exposing as shown in Table (5).

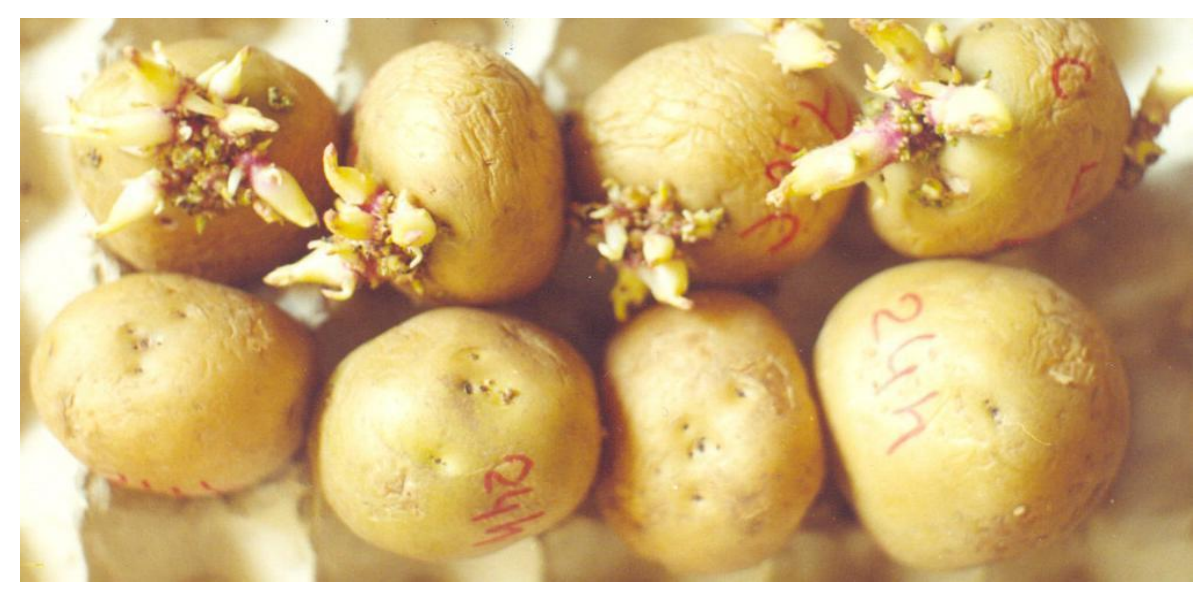

Fig. 3. Effect of storage of tubers exposed to ES at cool temperature on sprouting

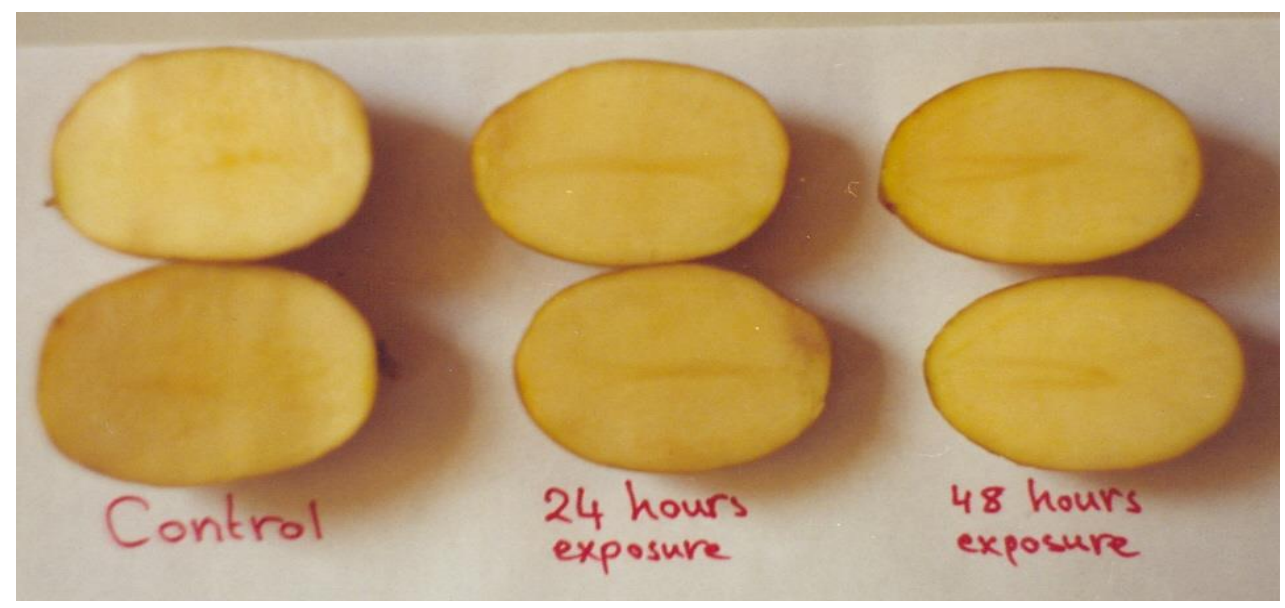

Fig. 4. Longitudinal sections of tubers exposed to ES vapour for 24 or $48 \mathrm{~h}$ or not-exposed 
Table 5. Effect of exposing potato tubers to vapour of ES resulted from evaporation of $0.125 \mathrm{ml} /$ liter space and stored for 4 months at ambient temperature on rots incidence

\begin{tabular}{|cccc|}
\hline \multirow{2}{*}{ Treatment } & \multicolumn{3}{c|}{ Rot* $^{*}$} \\
\cline { 2 - 4 } & $\begin{array}{c}\text { Erwinia } \\
\text { soft rot }\end{array}$ & $\begin{array}{c}\text { Fusarium } \\
\text { tuber rot }\end{array}$ & $\begin{array}{c}\text { Penicillium } \\
\text { rot }\end{array}$ \\
\hline Control & 9 & 11 & 0 \\
$6 \mathrm{~h}$ & 8 & 12 & 0 \\
$12 \mathrm{~h}$ & 8 & 13 & 0 \\
$24 \mathrm{~h}$ & 6 & 11 & 0 \\
\hline
\end{tabular}

Data of stored tubers for each particular treatment

* Tuber showed both types of rots were counted twisely

Concerning sprouting, it was observed occurrence of stimulatory effect especially for tubers exposed for 6 or $12 \mathrm{~h}$. Twenty four hours exposing led to reduction of sprouting as shown in Table (6).

Table 6. Effect of exposing potato tubers to ES vapour resulted from evaporation of $0.125 \mathrm{ml} /$ liter space and stored for 4 months at ambient temperature on sprouting (data of 50 stored tubers).

\begin{tabular}{|cccc|}
\hline Treatment & $\begin{array}{c}\text { No. of } \\
\text { sprouted } \\
\text { tubers }\end{array}$ & $\begin{array}{c}\text { No. of } \\
\text { sprouts/tuber }\end{array}$ & $\begin{array}{c}\text { Length of the } \\
\text { longest } \\
\text { sprout/tuber }(\mathrm{cm})\end{array}$ \\
\hline $\begin{array}{c}\text { Control } \\
6 \mathrm{~h}\end{array}$ & 50 & $3.5 \pm 1.5$ & $4.8 \pm 1.1$ \\
$\begin{array}{c}\text { exposing } \\
12 \mathrm{~h}\end{array}$ & 50 & $5.6 \pm 1.3$ & $7.3 \pm 1.5$ \\
exposing & 50 & $8.2 \pm 2.2$ & $9.2 \pm 1.9$ \\
$24 \mathrm{~h}$ & 24 & $2.9 \pm 1.2$ & $3.2 \pm 1.5$ \\
\hline
\end{tabular}

\section{DISCUSSION}

Potato tubers under long term storage are suffering from two factors strongly affected tubers stored for human consumption-sprouting and rots incidence. Many trials were carried out to solve this very complex problem. Compounds that affect metabolic processes in tubers were tested as sprouting inhibitors such as benzothiazole, 1,4dimethylnaphthaline (Beveridge et al 1981). Maleic hydrazide (Singa and Sihombing, 1983), 2,4 $\mathrm{D}$ and CCC (El-Sayed et al 1988). CIPC (isopro-
pyl-N (3-Chlorophenyl)- carbamate (Mondy and Pannampalam, 1985; Pannamplam and Mondy, 1986; Orr et al 1994).

Although many of these compounds successfully suppress sprouting of potato tuber, from other side they greatly increase rots incidence in treated tubers. As far as we know, no any attempt was carried out to decrease rots incidence during long-term storage either in ambient temperature or under cooling.

In the present study we decided to use the divers effects of one of salicylic acid derivatives i.e. ethyl salicylic acid (ES) because its solution capable to evaporate quickly at room temperature. In order to achieve our goal we tested this vapour in different doses ranged from high dose (vapour produced from evaporation of $1 \mathrm{ml} \mathrm{ES/} \mathrm{liter} \mathrm{space)}$ to very low dose (vapour produced from evaporation of $0.125 \mathrm{ml} /$ liter space on sprouting and rots incidence.

High doses of ES vapour led to complete collapse of exposed tubers and on all tubers stored for 4 methods Erwinia soft rot and Fusarium tuber rot were found on all exposed tubers. Moreover, a new rot caused by Penicillium spp. was observed on exposed tubers. Half ml/liter space of ES was not better than $1 \mathrm{ml} \mathrm{ES/} \mathrm{liter} \mathrm{space.} \mathrm{It} \mathrm{caused} \mathrm{se-}$ vere phytotoxic effect on exposed tubers beside the appearance of Erwinia soft rot and Fusarium tuber rot.

These results led to suppose that ES vapour at high doses caused complete break down of natural resistance in exposed tubers.

Vapour produced from evaporation of 0.250 $\mathrm{ml} /$ liter space gave very interesting results. It caused complete suppression of sprouting even when storing was prolonged for 4 months at ambient temperature $\left(18-23^{\circ} \mathrm{C}\right)$ especially for tubers exposed for $24 \mathrm{~h}$ or $48 \mathrm{~h}$. Moreover, such dose led to induce resistance in exposed tubers, whereas Erwinia soft rot and Fusarium tuber rot was significantly decreased.

The tested dose and period had no any phytotoxic effect on the inner tissue of exposed tubers. Our experiment indicated also that storage of exposed tubers to such dose $(0.250 \mathrm{ml} /$ liter space for $24 \mathrm{~h})$ under cooling $\left(6-8^{\circ} \mathrm{C}\right)$ or under very high relative humidity had not any effect on the efficiency of ES.

Expose of tubers to very low dose (vapour produced from evaporation of $0.125 \mathrm{ml} /$ liter space) led to stimulatory effect on exposed tubers. It increased sprouting either in counts of sprouts or its length, but it had not effect on rots incidence. 
As a conclusion, it could be say that we have reached our goal when we exposed tubers to vapour of ES resulted from evaporation of $0.250 \mathrm{ml} /$ liter space for $24 \mathrm{~h}$., sprouting completely suppressed and rots incidence significantly reduced.

\section{REFERENCES}

Bergey's Manual of Determinative Bacteriology $9^{\text {th }}$ Ed (1994). Facultatively aneararobic Gram negative Rods. Group 1, Family Enterobacteriaceae. pp. 175; 179 \& 207-209; 230. John G. Holt; Noel R. Kieg; Peter H.A. Sneath; James T. Staley; Stanley, T. Williams (Eds). Williams and Wilkin, Baltimor, USA.

Beveridge, J. L.; J. Dalziel and H. J. Duncan (1981). The assessment of some volatile organic compounds as sprout suppressants for ware and seed potatoes. Potato Research (Netherlands) 24: 61-76.

Booth, C. (1971). The Genus Fusarium. 236 pp. Commonw. Mycol. Inst., Kew, Surrey, England.

Dalziel, J. and H.J. Duncan (1980). Studies on potato sprout suppressants. 4. The distribution of tecnazene in potato tubers and the effect of processing on residue levels. Potato Research 23: 405-411.

El-Sayed, H.A.; S.T. El-Afifi and H.M. AbdelNaby (1988). Effect of 2,4-D and CCC on the storage life of potato tubers (Egypt). J. Agric. Sci., Mansoura Univ. , Egypt 13: 289-293.

Gruner, R.; G. Strompern; A.J.P. Pfitzer and U.M. Pfrtzer (2003). Salicylic acid and the hypersensitive response initiate distinct signal transduction pathways in tobacco that converge on the as1-like element of the PR-1a promoter. EFBS 270: 4876-4886.

Kwon, G.; J.R. Hill; J.A. Corbett and M.L. McDamiel (1997). Effects of aspirin on nitric oxide formation and de novo protein synthesis by RIN m5 F cells and rat islets. Molecular Pharmacology 53: 398-405.

Mondy, N.Y. and R. Pannamplam (1985). Effect of sprout inhibiting isopropyl-N (3Chlorophenyl) - carbamate on total glycoalkaloid content of potatoes. J. Food Sci. USA 50: 258259.

Nawrath, C. and J.P. Metraux (1999). Salicylic acid induction deficient mutants of Arabidopsis express PR-2 and PR-5 and accumulate high levels of camalexin after pathogen inoculation. Plant Cell 11: 1393-1404.

Norman, C.; C.A. Howelll; A.H. Milar; J.M. Whelan and D.A. Day (2004). Salicylic acid is an uncoupler and inhibitor of mitochondrial electron transport. Plant Physiol. 134: 492-501.

Orr, P.H.; M.T. Glynn and J.M. Sacks (1994). Design and performance of a test facility for evaluating potato sprout inhibitors. Transactions of the ASAE USA 37: 1899-1905.

Pannamplam, R. and N.J. Mondy (1986). Effect of Sprout Inhibitor Isopropyl N-(3-Chlorophenyl) carbamate (CIPC) on Phenolic and Ascorbic Acid Content of Potatoes. J. Agric. Food Chem. 34: 262-263.

Pannamplam, R. and N.J. Mondy (1988). Effect of sprout inhibitors and nitrogen fertilization on nitrate-N content of potato tubers. J. Agric. Food Chem. 50: 1246-1248.

Rocher, F.; E. Chollet; C. Jonsse and L. Bonnemain (2005). Salicylic acid, an ambimobile molecular exhibiting a high ability to accumulate in the phloem. Plant Physiol. 141: 1684-1693.

Singa, R.M. and P. Sihombing (1983). Effect of maleic hydrazide concentrations on the sprouting of stored tuber seed. Bulletin. Penelitian Horticulture, Indonesia 10: 25-29.

Slininger, P.J.; D.A. Schisler; K.D. Burkhead and R.J. Bothast (2003). Postharvest biological control of potato sprouting by Fusarium Dry rot suppressive bacteria. Biocontrol Sci. Technol. 13: 477-494.

Sonnewald, U. (2001). Control of potato tuber sprouting. TRENDS in Plant Science 6: 333335.

Van, W.; F. Vliet and S. Hertog (1966). The analysis of sprout inhibitor residues in the potato tuber. Potato Research 9: 152-160.

Vernooij, B.; L. Friedrich; A. Morse; R. Kolditz-Jawhar; E. Ward; S. Uknes; H. Kessmann and J. Ryals (1994). Salicylic acid is not the translocated signal responsible for inducing systemic acquired resistance but is required in signal translocation. Plant Cell 6: 959-965.

Zhixin, X. and Z. Chen (1999). Salicylic acid induces rapid inhibition of mitochondrial electron transport and oxidative phosphorylation in tobacco cells. Plant Physiol. 120: 217-226. 